University of Nebraska - Lincoln

DigitalCommons@University of Nebraska - Lincoln

Stocker performance and production in mixed tall fescue-bermudagrass pastures of the Southern Piedmont USA

\author{
Alan J. Franzluebbers \\ USDA-Agricultural Research Service, alan.franzluebbers@ars.usda.gov \\ John A. Stuedemann \\ USDA-Agricultural Research Service \\ Dwight $\mathrm{H}$. Seman \\ USDA-Agricultural Research Service
}

Follow this and additional works at: https://digitalcommons.unl.edu/usdaarsfacpub

Franzluebbers, Alan J.; Stuedemann, John A.; and Seman, Dwight H., "Stocker performance and production in mixed tall fescue-bermudagrass pastures of the Southern Piedmont USA" (2012). Publications from USDA-ARS / UNL Faculty. 1487.

https://digitalcommons.unl.edu/usdaarsfacpub/1487

This Article is brought to you for free and open access by the U.S. Department of Agriculture: Agricultural Research Service, Lincoln, Nebraska at DigitalCommons@University of Nebraska - Lincoln. It has been accepted for inclusion in Publications from USDA-ARS / UNL Faculty by an authorized administrator of DigitalCommons@University of Nebraska - Lincoln. 


\title{
Stocker performance and production in mixed tall fescue-bermudagrass pastures of the Southern Piedmont USA
}

\author{
Alan J. Franzluebbers*, John A. Stuedemann, and Dwight H. Seman \\ USDA-Agricultural Research Service, 1420 Experiment Station Road, Watkinsville GA 30677, USA \\ *Corresponding author: alan.franzluebbers@ars.usda.gov
}

\begin{abstract}
Stocker performance and production from mixed cool- and warm-season perennial pastures are important determinants of agricultural sustainability that can be influenced by management. We evaluated the factorial combination of three sources of nutrient application (inorganic only, organic + inorganic combination, and organic only) and two forage utilization regimes [low grazing pressure (LGP) and high grazing pressure (HGP)] on steer stocking density and rate, performance and production during 7 years of pasture management \{tall fescue [Lolium arundinaceum (Schreb.) Darbysh.] overseeded into existing Coastal bermudagrass [Cynodon dactylon (L.) Pers.] sod\} on a Typic Kanhapludult in Georgia, USA. Nutrient source had few major impacts on responses, except for lower animal performance with organic fertilization (broiler litter) than with organic + inorganic and inorganic only fertilization, especially with LGP. Seasonal changes in stocking weight and rate occurred, not only as expected due to environmental conditions and dominant forage species present, but that also counteracted expected differences imposed by grazing pressure; signaling negative feedback of HGP on forage productivity. Steer performance was greatest in spring and summer under both grazing pressures, but was significantly reduced with increasing grazing pressure in the autumn and winter due to low forage availability. Across years, steer gain ha ${ }^{-1}\left(863 \mathrm{~kg} \mathrm{ha}^{-1}\right)$ was not different between grazing pressures, but gain ha ${ }^{-1}$ declined with time under HGP and was stable with time under LGP. Reducing grazing pressure to a moderate level can lead to equivalent steer production as HGP, and would likely contribute to a more sustainable balance among production, socio-economic and environmental goals. These multi-year results will help cattle producers in warm, moist climates design and implement more sustainable grazing systems.
\end{abstract}

Key words: botanical composition, broiler litter, cattle production, grazing pressure, organic fertilizer, stocking density

\section{Introduction}

Pastures occupy $\sim 50$ Mha of land in the eastern USA, and therefore, are a significant land use affecting the livelihoods of 0.85 million farms ${ }^{1}$. A variety of pasture management systems are employed in the region and there is a pressing need to investigate the long-term effects of grazing management on system ecology, productivity and environmental outcomes ${ }^{2}$.

Pastures in the southeastern USA are dominated by two primary perennial forages, i.e. warm-season bermudagrass [Cynodon dactylon (L.) Pers.] and cool-season tall fescue [Lolium arundinaceum (Schreb.) Darbysh.]. Bermudagrass fits well the hot and variably wet and dry conditions in the summer. In general, bermudagrass is more productive than tall fescue, and therefore fills the primary growing season. However, there is still a need for forage production during the long cool-season when bermudagrass is dormant (November through April). Tall fescue is one of the few perennial, cool-season forages that can withstand the hot, drought-prone conditions in summer.

The fungal endophyte [Neotyphodium coenophialum (Morgan-Jones and Gams) Glenn, Bacon, and Hanlin] association with tall fescue is a key determinant of tall fescue stand persistence under high grazing pressure (HGP), as well as of animal performance and production. Cattle responses to different tall fescue cultivars and endophyte associations have been studied in a number of environments and grazing management conditions ${ }^{3-6}$. Wild-endophyte-infected tall fescue persists better with grazing than endophyte-free associations ${ }^{3,7}$. Recently, novel-endophyte associations with tall fescue (producing low levels of ergot-alkaloids) have also proven to be more 
persistent than endophyte-free associations ${ }^{8-10}$. Prior to the development of novel-endophyte associations, persistence of tall fescue in intensively grazed pastures was considered viable only with wild-endophyte association.

'Coastal' bermudagrass is a productive and benchmark hybrid that has been studied in a number of environments and grazing management conditions ${ }^{11-14}$. Bermudagrass hybrids are more productive than common bermudagrass $^{11}$ and, therefore, are often recommended to be managed as monoculture forage stands to maximize productivity. In reality though, producers throughout the eastern USA often manage mixed stands of forages, either through intention via planting or default based on evolution of pastures through time from various grazing management strategies employed ${ }^{15}$. Mixed cool- and warm-season forages in the same pasture are expected to extend the grazing season on a particular pasture, confer greater resilience to environmental and management stresses, and could lead to greater sustainability of grassbased agriculture ${ }^{16}$.

Investigations of cattle responses to grazing of mixed cool- and warm-season perennial pastures have been limited and, therefore, recommendations are often based on results evaluating the two systems separately. For example in Arkansas, milk yield of cows grazing common bermudagrass in the summer (June through October) was $63 \pm 41 \%$ greater than that of cows grazing wildendophyte-infected tall fescue in the fall and spring (November through May) ${ }^{17}$. Seasonal rotation of grazing on separate bermudagrass and tall fescue pastures produced $38 \pm 22 \%$ greater milk yield than grazing solely on tall fescue. Milk fat was greater from cows rotated between bermudagrass and tall fescue on a seasonal basis than on either pasture alone, but milk protein was not affected by any pasture grazing system ${ }^{17}$.

Considering the extent of mixed forage stands of tall fescue and bermudagrass throughout the southeastern USA, there is a scientific void in the characterization of cattle responses to grazing in mixed forage stands. Therefore, our broad goal was to develop balanced, mixed forage stands of tall fescue and bermudagrass for greater year-round grazing. Understanding this complex agro-ecological system would help transfer technologically relevant information to small farmers, especially those with abundant poultry litter available as fertilizer. Yet, the dynamics of cattle responses to nutrient source and forage utilization regimes are largely unknown.

There is concern that high broiler litter application on wild-endophyte-infected tall fescue pastures will exacerbate fescue toxicosis, fescue foot and associated negative responses of animals consuming ergot-alkaloidcontaining forage $\mathrm{e}^{18,19}$. We wanted to test this hypothesis by conducting a multiple-year grazing experiment with low and high broiler-litter application rates against an inorganically fertilized control.

We also hypothesized that reducing grazing pressure would increase cattle performance due to greater forage availability, but would reduce cattle gain ha ${ }^{-1}$ due to reduced stocking rate. Towards the end of 5 years of management of bermudagrass pastures, cattle gain ha ${ }^{-1}$ appeared to have been compromised with HGP. We wanted to test whether this trend would continue with expansion of the grazing season following introduction of tall fescue to the forage base.

Our specific objective was to characterize cattle performance and productivity in response to nutrient source (inorganic only, organic + inorganic, and organic only) and forage utilization [low grazing pressure (LGP) and HGP] in a Coastal bermudagrass sod oversown with Georgia-5 wild-endophyte-infected tall fescue during the course of 7 years in the Piedmont of Georgia, USA.

\section{Materials and Methods}

A 15 -ha upland field $\left(33^{\circ} 22^{\prime} \mathrm{N}, 83^{\circ} 24^{\prime} \mathrm{W}\right)$ on a Typic Kanhapludult near Farmington, Georgia, previously in a 'Coastal' bermudagrass pasture experiment for 5 years ${ }^{20}$, was converted to mixed tall fescue-bermudagrass forage composition for this experiment beginning in autumn of 1998. Thirty-six experimental units were arranged in a randomized complete block design with 12 treatments in a split-plot arrangement in each of three blocks. Main plots were nutrient source and split-plots were forage utilization regime.

'Georgia-5' tall fescue with wild-type endophyte infection was drilled into 7-year-old stands of 'Coastal' bermudagrass ( 5 years differentially managed from 1994 to 1998 following 2 years of establishment in 1992) in November 1998 at a rate of $\sim 19 \mathrm{~kg}$ pure live seed ha ${ }^{-1}$. Prior to seeding in 1998, residual forage mass of bermudagrass in LGP paddocks $\left(\sim 3.5 \mathrm{Mgha}^{-1}\right)$ was cut, baled and removed. Forage harvest was not deemed necessary, or practically possible, in paddocks that were maintained under HGP $\left(\sim 1.6 \mathrm{Mgha}^{-1}\right)$, since light penetration through the canopy was considered adequate and little forage could be harvested. Drilling of tall fescue $\left(\sim 22 \mathrm{~kg}\right.$ pure live seedha $\left.{ }^{-1}\right)$ had to be repeated in October 1999 in all paddocks, and again in November 2000 in paddocks maintained under HGP due to extended drought conditions in 1999 and 2000 (Table 1), which limited tall fescue stand establishment.

Nutrient source treatments were: (1) inorganic only; (2) organic + inorganic; and (3) organic only. Nutrient application was targeted to supply $270 \mathrm{kgN} \mathrm{ha}^{-1}$ annually in three equally split applications as: (1) inorganic fertilizer with 18-9-18 N- $\mathrm{P}_{2} \mathrm{O}_{5}-\mathrm{K}_{2} \mathrm{O}$ broadcast in spring (February-April) and with $34-0-0\left(\mathrm{NH}_{4} \mathrm{NO}_{3}\right)$ broadcast in summer (May-July) and again in autumn (SeptemberNovember); (2) chicken broiler litter broadcast in spring and $34-0-0$ broadcast in summer and again in autumn; and (3) broiler litter broadcast in spring, summer and autumn. Actual yearly $\mathrm{N}$ application rates during the 7 years of this experiment were $261 \pm 38 \mathrm{~kg} \mathrm{Nha}^{-1}$ 


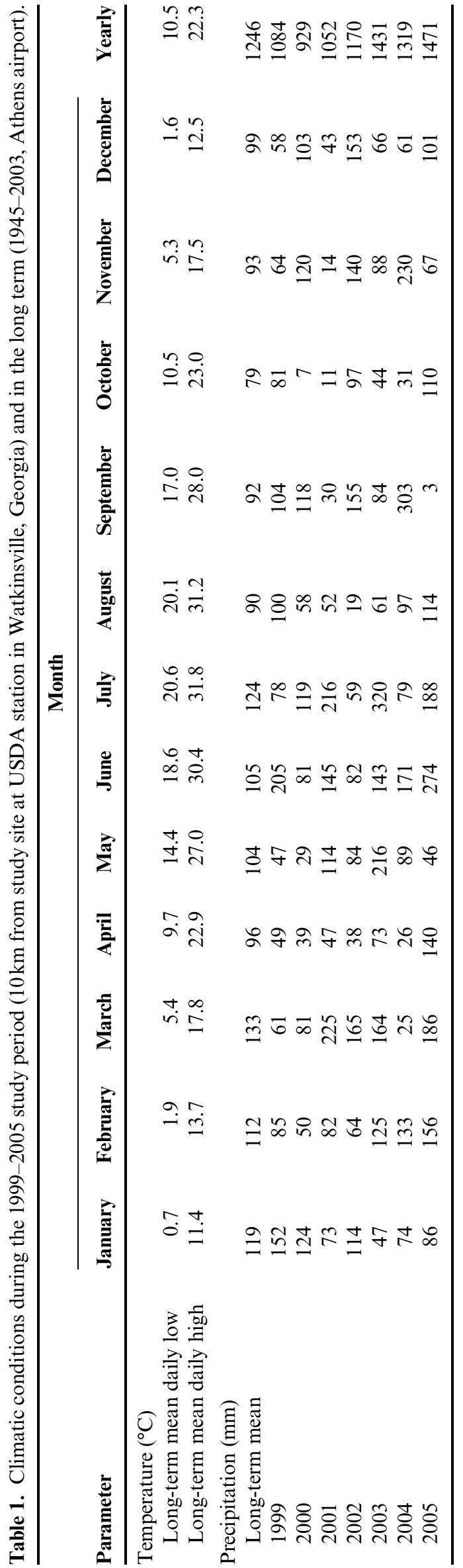

(inorganic only), $289 \pm 36 \mathrm{~kg} \mathrm{Nha}^{-1}$ (organic + inorganic) and $307 \pm 52 \mathrm{~kg} \mathrm{Nha}^{-1}$ (organic only), varying due to application with commercial-sized equipment and variable nutrient and moisture contents of broiler litter ${ }^{10}$.

Forage utilization regimes were two target forage mass levels in grazed paddocks: (1) high forage mass at a target of $2 \mathrm{Mgha}^{-1}$ (i.e., LGP) and (2) low-forage mass at a target of $1 \mathrm{Mgha}^{-1}$ (i.e., HGP). This study also had two ungrazed forage utilization regimes in small exclosures, but they were not considered here [(a) unharvested forage, except for an occasional woody plant removal, as a Conservation Reserve Program (CRP) simulation and (b) continuous hay removal on a monthly basis]. Grazed paddocks were $0.69 \pm 0.03$ ha. Spatial design of paddocks minimized runoff contamination and facilitated handling of cattle through a central roadway. Each paddock contained a $3 \times 4 \mathrm{~m}$ shade, mineral feeder and water trough placed in a line $15-\mathrm{m}$ long at the highest elevation.

Yearling Angus steers were used as stock (available herd of $115 \pm 24$ steers each grazing season; initial age of $\sim 7$ months; initial body weight of $249 \pm 17 \mathrm{~kg}$ in 1999 , $239 \pm 26 \mathrm{~kg}$ in $2000,212 \pm 30 \mathrm{~kg}$ in $2001,229 \pm 30 \mathrm{~kg}$ in $2002,217 \pm 34 \mathrm{~kg}$ in $2003,214 \pm 30 \mathrm{~kg}$ in 2004 and $218 \pm 21 \mathrm{~kg}$ in 2005 ; weaned just prior to stocking in autumn or wintered on pasture, hay and grain to gain $\geq 0.5 \mathrm{~kg} \mathrm{~d}^{-1}$ ). Cattle grazed paddocks nearly yearlong beginning in autumn until target forage mass levels could no longer be maintained, except in 1999 and 2000 when cattle were stocked beginning in spring to avoid grazing on young tall fescue stands. Stocking density was based on achieving the target forage mass of each treatment using a put-and-take grazing system ${ }^{21}$ with three tester steers permanently assigned to each paddock within a grazing season and grazer steers added or removed at 28-day intervals. Tester steers were randomly selected from three groups of 18; one group closest to the middle, one group immediately heavier, and one group immediately lighter than the mean weight. All body weight determinations were after $16 \mathrm{~h}$ without water while on paddock. Grazer steers were assigned in a similar manner from the remaining pool of animals. Grazer steers not allocated to an experimental paddock grazed an adjacent pasture of similar forage composition.

Before stocking in autumn (or spring starting times in 1999 and 2000), all steers received the following anthelmintic treatment: pour-on eprinex (Ivomec, Merial Limited, Iselin, New Jersey, USA) and oral albendazole (Valbazen, Pfizer, New York, USA) according to label recommendation based on steer weight. Cattle remained in dry-lot with feed and water for 3 days before stocking. Anthelmintic treatment was repeated in spring (AprilMarch).

On initial stocking and restocking days, steers were released into the central roadway early in the morning and corralled together to be weighed. Steer body weight was recorded from a digital balance under a 


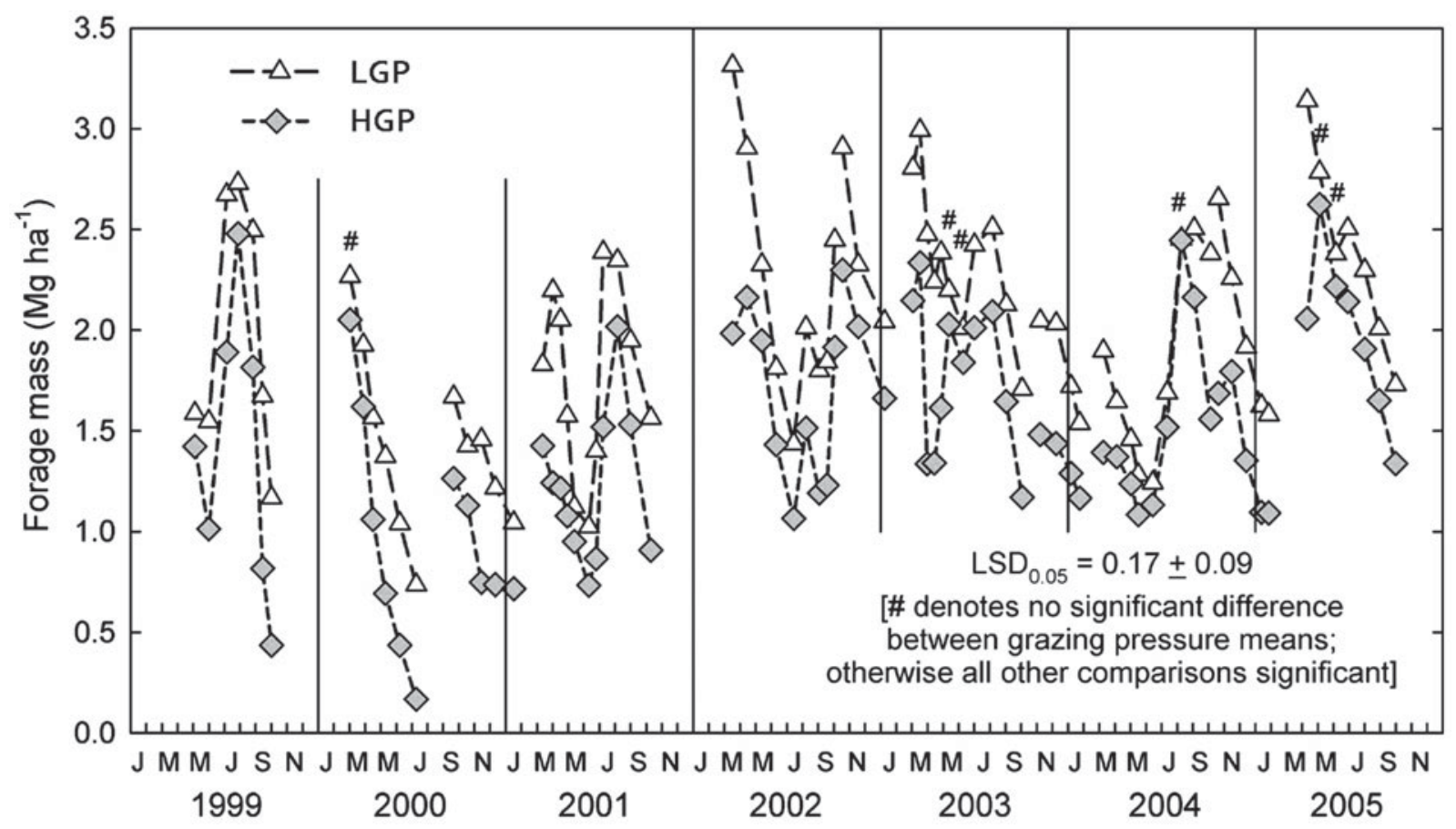

Figure 1. Actual forage mass as affected by grazing pressure level and sampling date within the 7 years of experimentation at Farmington, Georgia. Values are means across nutrient source $(n=3)$ levels. LGP, low grazing pressure; HGP. high grazing pressure.

chute. Steers were returned to paddocks mostly within $2 \mathrm{~h}$ of corralling.

Steer gain $\mathrm{ha}^{-1}$ was calculated as the difference in initial and final body weight of tester steers with proportionality adjustments for total number of steers on a paddock during a grazing period. Steer average daily gain was calculated from the difference in initial and final body weight of tester steers divided by the number of grazing days. Stocking rate was calculated as the mean number of steers on a pasture within the entire season divided by the paddock size $(0.65-$ 0.75 ha). Steer stocking weight was calculated from the average body weight of all steers on a paddock (i.e., initial and final body weights).

Response variables were analyzed for variance within each season, year, seasonal means across years, and annual means across years using the general linear model procedure of SAS (SAS Institute Inc., Cary, North Carolina, USA). With the split-plot arrangement of treatments, replication $\times$ nutrient source was the error term for the nutrient source effect and replication $\times$ nutrient source $\times$ forage utilization regime was the error term for forage utilization and nutrient source $\times$ forage utilization effects. Grazing season effects were considered a further split-plot in time, evaluated with the experimentwise error term. All effects were considered significant at $P \leq 0.1$. Although this was a lenient probability level, we did not want to overlook potentially important trends. Actual $\operatorname{Pr}>F$ values were also reported for many effects in tables. However, least significant differences were calculated at $P=0.05$.

\section{Results and Discussion}

\section{Environmental conditions}

Mean climatic conditions in the Piedmont region of Georgia are relatively mild and supportive of both cool-season and warm-season forages. January is the coldest month $\left(0.7^{\circ} \mathrm{C}\right.$ minimum and $11.4^{\circ} \mathrm{C}$ maximum $)$ and July is the warmest month $\left(20.6^{\circ} \mathrm{C}\right.$ minimum and $31.8^{\circ} \mathrm{C}$ maximum) (Table 1). Precipitation among months is normally relatively uniformly distributed, $104 \pm 16 \mathrm{~mm}$ month ${ }^{-1}$. Precipitation during the 7 -year period was $97 \pm 16 \%$ of normal yearly values. However, precipitation varied greatly from the mean monthly values, resulting in periods of drought and excess precipitation. Compared with $75-125 \%$ of the normal monthly precipitation range, there were $45 \%$ of months with below-normal precipitation and $26 \%$ of months with above-normal precipitation, leaving only $29 \%$ of the months with normal precipitation. Extended drought periods ( $\geq 3$ consecutive months with below-normal precipitation) occurred from March to May 1999 (47\% of normal precipitation), February to May 2000 (45\% of normal), August to December 2001 (33\% of normal), April to August 2002 (54\% of normal), and August 2003 to January 2004 (73\% of normal).

\section{Residual forage dry mass}

Standing forage dry mass throughout the 7-year period varied within a year (Fig. 1), among years, and as 


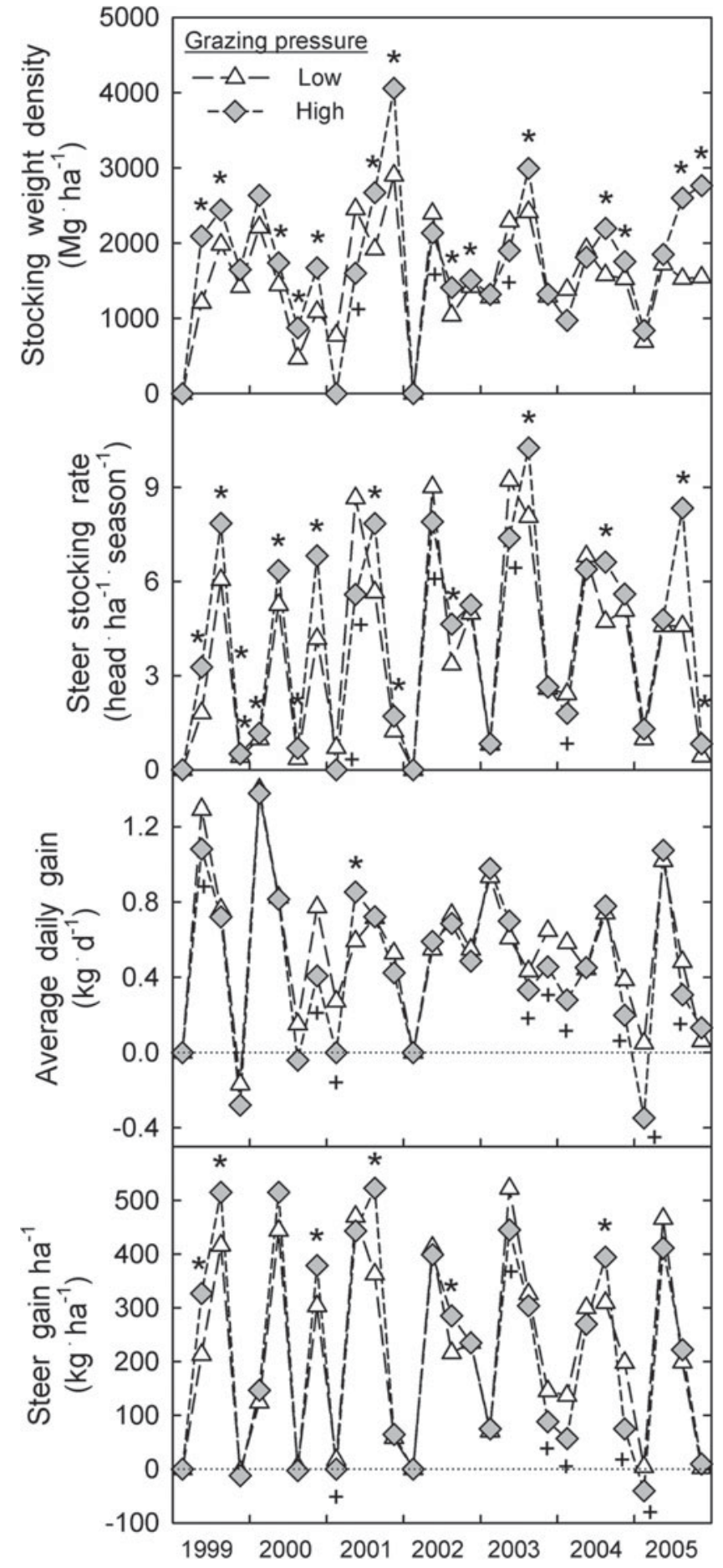

Figure 2. Seasonal changes in steer stocking weight density, stocking rate, average daily gain and gain ha ${ }^{-1}$ as affected by grazing pressure treatment throughout the 7 years of experimentation at Farmington, Georgia. Values are means across nutrient source $(n=3)$ levels. *Indicates LGP lower than HGP $(P<0.05)$ and + indicates LGP greater than HGP $(P<0.05)$.

intended, between grazing pressure treatments. Over the course of the entire 7-year period, there were no differences in standing forage dry mass among nutrient sources (data not shown). Within a total of 77 individual dates of forage dry mass determination, there were only six times when standing forage dry mass was not significantly different between grazing pressure treatments.

Standing forage dry mass varied within and among years due to the relatively long periods ( 28 days) between planned steer weighing dates, variations in precipitation that altered forage growth rate, and limited number of steers available for stocking. Despite these variations, forage dry mass remained relatively consistently different between grazing pressure treatments throughout (i.e., difference between means was $0.50 \pm 0.26 \mathrm{Mg} \mathrm{ha}^{-1}$ among the 77 dates). This was a managed difference, and therefore, was intentionally consistent.

\section{Stocking density}

Steer stocking density varied within a year, among years, and between grazing pressure treatments (Fig. 2). The effect of nutrient source on stocking density was rarely significant. Stocking density was lower with LGP than with HGP in 14 of 28 seasons, was similar between treatments in 11 seasons, and was greater with LGP than with HGP in three seasons. Across years, stocking density was lower with LGP than with HGP in the autumn when steers were youngest and exposed to pastures for the first time during the year $\left(1.41\right.$ versus $1.74 \mathrm{Mg} \mathrm{ha}^{-1}$, respectively; $P<0.001)$. Forage dry mass at the beginning of the four autumns in which yearling steers were stocked was $2.32 \pm 0.56 \mathrm{Mg} \mathrm{ha}^{-1}$ under LGP and $1.68 \pm 0.45 \mathrm{Mg} \mathrm{ha}^{-1}$ under HGP, values that exceeded our target forage mass levels, and therefore could support differential stocking. In winter and spring, stocking density was reversed in order relative to grazing pressure, in which stocking density was greater with LGP than with HGP (in winter: 1.15 versus $0.94 \mathrm{Mgha}^{-1}$, respectively; $P=0.005$; in spring: 1.99 versus $1.85 \mathrm{Mgha}^{-1}$, respectively; $P=0.03$ ). This apparent discrepancy of response relative to imposed treatment regime was a long-term consequence of managing pastures to a target forage mass level rather than on set stocking conditions. In summer, stocking returned to lower density with LGP than with HGP (1.69 versus $2.33 \mathrm{Mg} \mathrm{ha}^{-1}$, respectively; $\left.P<0.001\right)$ due to rapid forage growth. A significant interaction between nutrient source and grazing pressure also occurred in summer, due to greater difference in stocking density between grazing pressure levels with organic fertilization than with inorganic only and organic + inorganic fertilization.

Over the entire 7-year period, stocking density was lower with LGP than with HGP, but the magnitude of difference varied with nutrient source (i.e., 1.72 versus $1.99 \mathrm{Mgha}^{-1}$ with inorganic fertilization, 1.72 versus $1.91 \mathrm{Mgha}^{-1}$ with organic + inorganic fertilization, and 1.64 versus $1.99 \mathrm{Mg} \mathrm{ha}^{-1}$ with organic fertilization) (Table 2). Steer stocking density varied among years, but this variation was not related to variation in precipitation 
Table 2. Steer stocking weight density of each year as affected by nutrient source and forage utilization regimes from 1999 to 2005 at Farmington, Georgia.

\begin{tabular}{|c|c|c|c|c|c|c|c|c|c|}
\hline \multirow[b]{2}{*}{ Nutrient source } & \multirow{2}{*}{$\begin{array}{l}\text { Forage } \\
\text { utilization }\end{array}$} & \multicolumn{8}{|c|}{ Year of evaluation } \\
\hline & & 1999 & 2000 & 2001 & 2002 & 2003 & 2004 & 2005 & 7-year mean \\
\hline & & \multicolumn{8}{|c|}{ 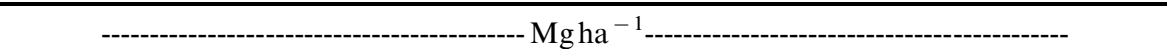 } \\
\hline Inorganic & LGP & 1.80 & 1.30 & 1.96 & 1.73 & 2.12 & 1.69 & 1.40 & 1.72 \\
\hline Inorganic & HGP & 2.39 & 1.70 & 2.01 & 1.75 & 2.21 & 1.81 & 2.03 & 1.99 \\
\hline Organic + inorganic & LGP & 1.80 & 1.21 & 2.14 & 1.58 & 2.10 & 1.66 & 1.53 & 1.72 \\
\hline Organic + inorganic & HGP & 2.28 & 1.67 & 1.97 & 1.63 & 2.06 & 1.73 & 2.03 & 1.91 \\
\hline Organic & LGP & 1.60 & 1.19 & 2.15 & 1.51 & 2.03 & 1.57 & 1.46 & 1.64 \\
\hline Organic & HGP & 2.20 & 1.61 & 2.18 & 1.68 & 2.21 & 1.85 & 2.18 & 1.99 \\
\hline \multicolumn{2}{|c|}{$\begin{array}{l}\text { LSD }(\mathrm{P}=0.05) \text { among nutrient } \\
\text { source } \times \text { forage utilization means }\end{array}$} & 0.20 & 0.12 & 0.18 & 0.13 & 0.24 & 0.12 & 0.20 & 0.07 \\
\hline \multicolumn{10}{|c|}{ Nutrient source means } \\
\hline Inorganic & & 2.09 & 1.50 & 1.99 & 1.74 & 2.16 & 1.75 & 1.72 & 1.85 \\
\hline Organic + inorganic & & 2.04 & 1.44 & 2.06 & 1.61 & 2.08 & 1.69 & 1.78 & 1.81 \\
\hline Organic & & 1.90 & 1.40 & 2.16 & 1.60 & 2.12 & 1.71 & 1.82 & 1.82 \\
\hline \multicolumn{10}{|l|}{ Forage utilization means } \\
\hline LGP & & 2.29 & 1.66 & 2.05 & 1.69 & 2.16 & 1.80 & 2.08 & 1.96 \\
\hline HGP & & 1.73 & 1.23 & 2.09 & 1.61 & 2.08 & 1.64 & 1.46 & 1.69 \\
\hline Source of variation & df & \multicolumn{8}{|c|}{ Pr $>F_{-}$} \\
\hline Nutrient source (NS) & 2 & 0.42 & 0.13 & 0.33 & 0.13 & 0.78 & 0.78 & 0.81 & 0.89 \\
\hline Forage utilization (FU) & 1 & $<0.001$ & $<0.001$ & 0.46 & 0.04 & 0.22 & 0.002 & $<0.001$ & $<0.001$ \\
\hline $\mathrm{NS} \times \mathrm{FU}$ & 2 & 0.56 & 0.69 & 0.13 & 0.16 & 0.34 & 0.06 & 0.24 & 0.04 \\
\hline
\end{tabular}

LPG, low grazing pressure; HGP, high grazing pressure.

among years. The difference in stocking density between grazing pressure treatments was greatest in 1999 and 2005 and there was no difference in stocking density between grazing pressure treatments in 2001 and 2003. Stocking density was a pasture management tool used to manipulate forage to the desired targets we set as part of the treatment structure in this experiment. However, stocking density was also a pasture response reflecting inherent forage productivity dictated by nutrient source effects on nutrient availability and long-term canopy manipulation on pasture growth.

\section{Stocking rate}

Steer stocking rate differed from stocking density in this study, because stocking rate was calculated as the number of steers on a pasture during the entire season, not just when pastures were stocked. Stocking rate also varied widely within a year, among years, and between grazing pressure treatments (Fig. 2). Like that of stocking density, the effect of nutrient source on stocking rate was rarely significant. Stocking rate was lower with LGP than with HGP in 15 of 28 seasons, was similar between treatments in only eight seasons, and was greater with LGP than with HGP in five seasons. Stocking rate was lowest in winter, highest in spring and summer, and intermediate in autumn-responses reflecting environmental conditions controlling pasture productivity. Like that of stocking density, stocking rate was greater with LGP than with
HGP in the winter $\left(0.8\right.$ versus 0.7 steers ha $^{-1}$, respectively; $P=0.02)$ and in the spring (6.5 versus 6.0 steersha $^{-1}$, respectively; $P=0.03$ ), but lower with LGP than with HGP in the summer (4.6 versus 6.6 steers ha $^{-1}$, respectively; $P<0.001)$ and in the autumn $(2.7$ versus 3.3 steers ha $^{-1}$, respectively; $\left.P<0.001\right)$.

Seasonal fluctuations in stocking rate were largely a function of available forage for grazing. Under LGP, the greatest stocking rate was in the spring, which was likely due to the large flush of tall fescue growth. Lower stocking rate in summer than in spring with LGP was also likely due to suppression of bermudagrass by tall fescue ${ }^{22}$. Under HGP, the greatest stocking rate was in the summer, which was likely due to greater production of bermudagrass when pastures were maintained with low forage dry mass $^{22}$.

Over the entire 7-year period, stocking rate was lower with LGP than with HGP (3.7 versus 4.2 steers ha $^{-1}$ ) (Table 3). Steer stocking rate varied among years, and unlike that of stocking density, stocking rate tended to increase with increasing yearly precipitation. This positive association with precipitation was likely related to greater forage production with increasing precipitation. Stocking rate was significantly lower with LGP than with HGP in 1999, 2000, 2004, and 2005, but not different between treatments in 2002 and 2003. In 2001, stocking rate was even greater with LGP than with HGP, but this effect was mainly due to the differential response in organic + inorganic fertilization, whereas no difference occurred 
Table 3. Steer stocking rate proportional to the entire year as affected by nutrient source and forage utilization regimes from 1999 to 2005 at Farmington, Georgia.

\begin{tabular}{|c|c|c|c|c|c|c|c|c|c|}
\hline \multirow[b]{2}{*}{ Nutrient source } & \multirow{2}{*}{$\begin{array}{l}\text { Forage } \\
\text { utilization }\end{array}$} & \multicolumn{8}{|c|}{ Year of evaluation } \\
\hline & & 1999 & 2000 & 2001 & 2002 & 2003 & 2004 & 2005 & 7-year mean \\
\hline & & \multicolumn{8}{|c|}{ 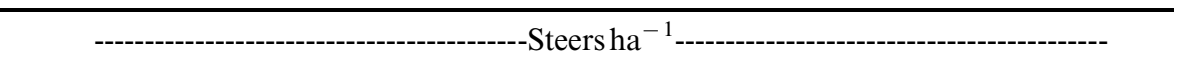 } \\
\hline Inorganic & LGP & 2.2 & 2.8 & 3.7 & 4.6 & 5.3 & 4.9 & 2.5 & 3.7 \\
\hline Inorganic & HGP & 3.0 & 3.9 & 3.8 & 4.7 & 5.6 & 5.1 & 3.7 & 4.3 \\
\hline Organic + inorganic & LGP & 2.1 & 2.6 & 4.2 & 4.2 & 5.2 & 4.8 & 2.8 & 3.7 \\
\hline Organic + inorganic & HGP & 2.9 & 3.7 & 3.6 & 4.2 & 4.9 & 5.0 & 3.7 & 4.0 \\
\hline Organic & LGP & 2.0 & 2.6 & 4.2 & 4.1 & 5.0 & 4.6 & 2.6 & 3.6 \\
\hline Organic & HGP & 2.8 & 3.7 & 4.0 & 4.4 & 5.3 & 5.2 & 4.1 & 4.2 \\
\hline \multicolumn{2}{|c|}{$\begin{array}{l}\text { LSD }(P=0.05) \text { among nutrient } \\
\text { source } \times \text { forage utilization means }\end{array}$} & 0.2 & 0.2 & 0.4 & 0.3 & 0.6 & 0.4 & 0.5 & 0.3 \\
\hline \multicolumn{10}{|l|}{ Nutrient source means } \\
\hline Inorganic & & 2.6 & 3.3 & 3.7 & 4.7 & 5.5 & 5.0 & 3.1 & 4.0 \\
\hline Organic + inorganic & & 2.5 & 3.2 & 3.9 & 4.2 & 5.1 & 4.9 & 3.2 & 3.9 \\
\hline Organic & & 2.4 & 3.1 & 4.1 & 4.3 & 5.1 & 4.9 & 3.4 & 3.9 \\
\hline \multicolumn{10}{|l|}{$\begin{array}{l}\text { Forage utilization } \\
\text { means }\end{array}$} \\
\hline LGP & & 2.1 & 2.7 & 4.1 & 4.3 & 5.2 & 4.8 & 2.6 & 3.7 \\
\hline HGP & & 2.9 & 3.8 & 3.8 & 4.4 & 5.3 & 5.1 & 3.8 & 4.2 \\
\hline Source of variation & df & \multicolumn{8}{|c|}{$\mathrm{Pr}>\mathrm{F}-$} \\
\hline Nutrient source (NS) & 2 & 0.40 & 0.09 & 0.19 & 0.15 & 0.47 & 0.91 & 0.76 & 0.76 \\
\hline Forage utilization (FU) & 1 & $<0.001$ & $<0.001$ & 0.03 & 0.21 & 0.50 & 0.01 & $<0.001$ & $<0.001$ \\
\hline $\mathrm{NS} \times \mathrm{FU}$ & 2 & 0.66 & 0.83 & 0.06 & 0.28 & 0.24 & 0.16 & 0.29 & 0.13 \\
\hline
\end{tabular}

LPG, low grazing pressure; HGP, high grazing pressure.

between grazing pressure treatments with other fertilization regimes. A lone nutrient source effect also occurred in 2000 when stocking rate was greater with inorganic than with organic fertilization. This response was likely due to greater residual forage dry mass that accumulated with inorganic than with organic fertilization in $1999^{22}$, which would have contributed to lower forage availability and stocking rate potential.

Stocking rate was lower during the first phase of this experiment (i.e., 5 years of grazing bermudagrass only from May to September) [Phase 1: 2.2 and 3.3 steers ha $^{-1}$ with LGP and HGP, respectively (yearly values projected from 5.8 and 8.7 steers ha $^{-1}$ during $140 \mathrm{~d}$ ); Phase 2: 3.7 and 4.2 steers ha $\left.^{-1}\right)^{20}$ (Table 3). Extension of the grazing season with the introduction of tall fescue into existing bermudagrass sod allowed more grazing days each year (140 days in Phase 1 and $237 \pm 53$ days in Phase 2). However, the additional grazing days were associated with lower cool-season production resulting in lowstocking rates in autumn and winter $\left(\sim 2\right.$ steersha $\left.^{-1}\right)$.

\section{Average daily gain}

Performance of steers on pasture (i.e., average daily gain; $\mathrm{kg} \mathrm{d}^{-1}$ ) varied widely within a year, among years and between grazing pressure treatments (Fig. 2). Nutrient source also significantly impacted steer performance in several instances. Average daily gain on a seasonal basis was more often similar between grazing pressure treatments (18 of 28 seasons) than different. When differences occurred, 9 of 10 seasons had greater daily gain with LGP than with HGP and only one season had lower daily gain with LGP than with HGP. Variation in average daily gain was particularly high among the 28 continuous seasons, with steer weight loss occurring in three seasons, although all of these observations coincided with very low stocking rate, suggestive of poor grazing conditions with low forage availability. The coefficient of variation among the 28 seasons was lower with LGP $(69 \%)$ than with $\operatorname{HGP}(90 \%)$, suggesting that weather stresses on steer performance could be somewhat alleviated with LGP. Therefore, adaptability of grazing management to the vagaries of weather conditions could be considered more suitable with LGP by allowing a buffer of residual forage mass to overcome the strong time dependence between forage growth and consumption.

Average daily gain was greater with LGP than with HGP in the autumn $\left(0.55\right.$ versus $0.35 \mathrm{~kg} \mathrm{~d}^{-1}$, respectively; $P=0.001)$, in the winter $\left(0.50\right.$ versus $0.24 \mathrm{~kg} \mathrm{~d}^{-1}$, respectively; $P<0.001)$, and in the summer $(0.63$ versus $0.57 \mathrm{~kg} \mathrm{~d}^{-1}$, respectively; $P=0.006$ ). In contrast, average daily gain was lower with LGP than with HGP in the spring ( 0.70 versus $0.76 \mathrm{~kg} \mathrm{~d}^{-1}$, respectively; $P=0.02$ ). These seasonal fluctuations in average daily gain suggest that LGP created a forage production - cattle consumption environment that was more stable 
Table 4. Steer average daily gain for each year as affected by nutrient source and forage utilization regimes from 1999 to 2005 at Farmington, Georgia.

\begin{tabular}{|c|c|c|c|c|c|c|c|c|c|}
\hline \multirow[b]{2}{*}{ Nutrient source } & \multirow{2}{*}{$\begin{array}{l}\text { Forage } \\
\text { utilization }\end{array}$} & \multicolumn{8}{|c|}{ Year of evaluation } \\
\hline & & 1999 & 2000 & 2001 & 2002 & 2003 & 2004 & 2005 & 7-year mean \\
\hline & & \multicolumn{8}{|c|}{ 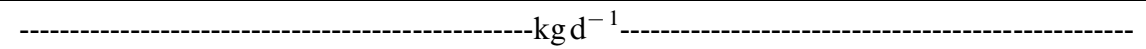 } \\
\hline Inorganic & LGP & 0.87 & 0.74 & 0.69 & 0.69 & 0.57 & 0.56 & 0.55 & 0.67 \\
\hline Inorganic & HGP & 0.75 & 0.64 & 0.65 & 0.55 & 0.46 & 0.45 & 0.49 & 0.57 \\
\hline Organic + inorganic & LGP & 0.89 & 0.84 & 0.57 & 0.66 & 0.59 & 0.55 & 0.57 & 0.67 \\
\hline Organic + inorganic & HGP & 0.78 & 0.58 & 0.75 & 0.60 & 0.56 & 0.45 & 0.40 & 0.59 \\
\hline Organic & LGP & 0.75 & 0.70 & 0.56 & 0.51 & 0.54 & 0.50 & 0.61 & 0.60 \\
\hline Organic & HGP & 0.72 & 0.54 & 0.65 & 0.64 & 0.57 & 0.49 & 0.48 & 0.58 \\
\hline \multicolumn{2}{|c|}{$\begin{array}{l}\mathrm{LSD}(P=0.05) \text { among nutrient } \\
\quad \text { source } \times \text { grazing pressure means }\end{array}$} & 0.19 & 0.12 & 0.03 & 0.12 & 0.06 & 0.09 & 0.12 & 0.03 \\
\hline \multicolumn{10}{|l|}{ Nutrient source means } \\
\hline Inorganic & & 0.81 & 0.69 & 0.67 & 0.62 & 0.52 & 0.50 & 0.52 & 0.62 \\
\hline Organic + inorganic & & 0.83 & 0.71 & 0.66 & 0.63 & 0.58 & 0.50 & 0.49 & 0.63 \\
\hline Organic & & 0.74 & 0.62 & 0.61 & 0.58 & 0.56 & 0.50 & 0.54 & 0.59 \\
\hline \multicolumn{10}{|l|}{ Forage utilization means } \\
\hline LGP & & 0.84 & 0.76 & 0.61 & 0.62 & 0.57 & 0.54 & 0.58 & 0.64 \\
\hline HGP & & 0.75 & 0.59 & 0.68 & 0.60 & 0.53 & 0.46 & 0.46 & 0.58 \\
\hline Source of variation & df & \multicolumn{8}{|c|}{ - $\mathrm{Pr}>\mathrm{F}$} \\
\hline Nutrient source (NS) & 2 & 0.35 & 0.02 & 0.18 & 0.17 & 0.003 & 0.90 & 0.63 & 0.006 \\
\hline Forage utilization (FU) & 1 & 0.08 & $<0.001$ & $<0.001$ & 0.48 & 0.03 & 0.01 & 0.006 & $<0.001$ \\
\hline $\mathrm{NS} \times \mathrm{FU}$ & 2 & 0.67 & 0.15 & $<0.001$ & 0.02 & 0.02 & 0.16 & 0.40 & 0.01 \\
\hline
\end{tabular}

LPG, low grazing pressure; HGP, high grazing pressure.

throughout the year than under HGP. The lower steer performance under LGP than under HGP in the spring was likely due to the unexpectedly greater steer stocking rate in the spring to consume the greater tall fescue forage accumulation left after the winter under LGP.

The difference in average daily gain between LGP and HGP treatments in winter was greater with organic + inorganic fertilization $\left(0.54\right.$ versus $0.17 \mathrm{~kg} \mathrm{~d}^{-1}$, respectively) than with inorganic only and organic only $(0.47$ versus $0.27 \mathrm{~kg} \mathrm{~d}^{-1}$, respectively), but this effect was simply a matter of magnitude not of order. The difference in average daily gain between LGP and HGP treatments in summer was significant for inorganic only and organic + inorganic fertilization $\left(0.66\right.$ versus $0.55 \mathrm{~kg} \mathrm{~d}^{-1}$, respectively), but not for organic fertilization $\left(0.58 \mathrm{~kg} \mathrm{~d}^{-1}\right)$. It is unclear why this interaction occurred, since the stocking rate was consistently lower with LGP than with HGP in the summer from all three nutrient source treatments (4.6 versus 6.6 steers ha $^{-1}$ ). Average daily gain was also greater with inorganic only and organic + inorganic fertilization $\left(0.75 \mathrm{~kg} \mathrm{~d}^{-1}\right)$ than with organic only fertilization $\left(0.68 \mathrm{~kg} \mathrm{~d}^{-1}\right)$ in the spring. Lower daily gain with organic fertilization might have been due to a numerically greater $(P>0.1)$ stocking rate than with other fertilization strategies $\left(6.4\right.$ versus 6.1 steers ha $\left.^{-1}\right)$ in the summer.

Over the entire 7-year period, average daily gain was greater with LGP than with HGP (0.64 versus
$0.58 \mathrm{~kg} \mathrm{~d}^{-1}$ ) (Table 4). Average daily gain tended to decline with time (and precipitation due to covariance). This may have been a consequence of greater time of stocking during winter and autumn in later years of this study than in earlier years. These two periods produced the lowest steer performance, especially under HGP. Consumption of toxic ergot alkaloids in the wild-typeendophyte association of tall fescue was a likely contribution to the depression in cattle performance during the cool seasons ${ }^{6}$.

Average daily gain was significantly greater with LGP than with HGP in 1999, 2000, 2003, 2004 and 2005, but not different between treatments in 2002. In 2001, average daily gain was lower with LGP than with HGP in organic + inorganic and organic only fertilization, but greater with LGP than with HGP in inorganic fertilization. A similar disparity in response occurred in 2002 and 2003. It is not clear why broiler litter as part of the fertilization strategy under LGP might have reduced steer performance, but high $\mathrm{P}$ input with broiler litter has been hypothesized to exacerbate fescue toxicosis symptoms (J.A. Stuedemann, unpublished data) and this response should be investigated further in other experimental conditions. Nutrient source main effects were also significant in 2000 and 2003, in which organic + inorganic fertilization was greater than other sources. Again, these are curious results that require further mechanistic investigations to fully understand. 
Table 5. Steer gain $\mathrm{ha}^{-1}$ for each year as affected by nutrient source and forage utilization regimes from 1999 to 2005 at Farmington, Georgia.

\begin{tabular}{|c|c|c|c|c|c|c|c|c|c|}
\hline \multirow[b]{2}{*}{ Nutrient source } & \multirow{2}{*}{$\begin{array}{l}\text { Forage } \\
\text { utilization }\end{array}$} & \multicolumn{8}{|c|}{ Year of evaluation } \\
\hline & & 1999 & 2000 & 2001 & 2002 & 2003 & 2004 & 2005 & 7-year-mean \\
\hline & & \multicolumn{8}{|c|}{ 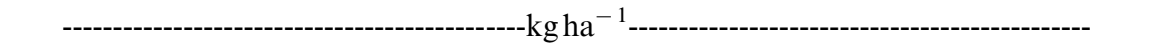 } \\
\hline Inorganic & LGP & 680 & 938 & 970 & 1000 & 1081 & 980 & 610 & 894 \\
\hline Inorganic & HGP & 859 & 1080 & 950 & 911 & 808 & 727 & 617 & 850 \\
\hline Organic + inorganic & LGP & 671 & 887 & 874 & 872 & 1107 & 975 & 685 & 868 \\
\hline Organic + inorganic & HGP & 852 & 1035 & 1056 & 862 & 901 & 795 & 509 & 859 \\
\hline Organic & LGP & 523 & 804 & 878 & 719 & 1003 & 877 & 718 & 789 \\
\hline Organic & HGP & 779 & 999 & 1086 & 986 & 1028 & 865 & 683 & 918 \\
\hline \multicolumn{2}{|c|}{$\begin{array}{l}\mathrm{LSD}(P=0.05) \text { among nutrient } \\
\quad \text { source } \times \text { grazing pressure means }\end{array}$} & 188 & 182 & 93 & 192 & 146 & 136 & 197 & 83 \\
\hline \multicolumn{10}{|c|}{ Nutrient source means } \\
\hline Inorganic & & 769 & 1009 & 960 & 956 & 944 & 854 & 613 & 872 \\
\hline Organic + inorganic & & 762 & 961 & 965 & 867 & 1004 & 885 & 597 & 863 \\
\hline Organic & & 651 & 901 & 982 & 852 & 1016 & 871 & 701 & 853 \\
\hline \multicolumn{10}{|l|}{ Forage utilization means } \\
\hline LGP & & 625 & 876 & 907 & 864 & 1064 & 944 & 671 & 850 \\
\hline HGP & & 830 & 1038 & 1030 & 919 & 912 & 796 & 603 & 876 \\
\hline Source of variation & df & 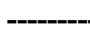 & & & $-P r$ & & & & ---- \\
\hline Nutrient source (NS) & 2 & 0.19 & 0.28 & 0.88 & 0.16 & 0.71 & 0.73 & 0.17 & 0.87 \\
\hline Forage utilization $(\mathrm{FU})$ & 1 & 0.004 & 0.009 & 0.001 & 0.26 & 0.005 & 0.004 & 0.19 & 0.24 \\
\hline $\mathrm{NS} \times \mathrm{FU}$ & 2 & 0.74 & 0.86 & 0.01 & 0.04 & 0.03 & 0.05 & 0.31 & 0.02 \\
\hline
\end{tabular}

LPG, low grazing pressure; HGP, high grazing pressure.

Compared with Phase 1 of this experiment, average daily gain declined with introduction of tall fescue into the bermudagrass sod (Phase 1: 0.88 and $0.67 \mathrm{~kg} \mathrm{~d}^{-1}$ with LGP and HGP, respectively, versus Phase 2: 0.64 and $0.58 \mathrm{~kg} \mathrm{~d}^{-1}$ ). Considering only the spring and summer grazing seasons in Phase 2, average daily gain was $0.67 \mathrm{~kg}$ $\mathrm{d}^{-1}$ under both grazing pressures, and therefore, equivalent to that under HGP in Phase 1. Dilution of ergotalkaloid containing forage with other forages has been a recommended practice for overcoming toxicity issues in tall fescue pastures ${ }^{23}$. Average daily gain when tall fescue was the dominant forage (cool seasons of autumn and winter) was low $\left(0.52\right.$ and $0.29 \mathrm{~kg} \mathrm{~d}^{-1}$ with LGP and HGP, respectively), and was likely a consequence of steers consuming ergot-alkaloid containing forage. Average daily gain of heifers grazing tall fescue in a nearby study was $0.54 \mathrm{~kg} \mathrm{~d}^{-1}$ on wild-endophyte association and $0.75 \mathrm{~kg} \mathrm{~d}^{-1}$ on novel-endophyte and endophyte-free associations $^{24}$, a clear indication of depression of animal performance with consumption of ergot-alkaloid containing forage. Greatest depression in animal performance occurred in spring and autumn in this neighboring study, followed closely by depression in winter, but there was no effect on animal performance in summer. Interestingly, our results reported here suggested no depressive effect of consuming tall fescue forage in the spring (average daily gain was $0.7 \mathrm{~kg} \mathrm{~d}^{-1}$ in spring and $0.6 \mathrm{~kg} \mathrm{~d}^{-1}$ in summer).
Reduction in steer grazing pressure led to somewhat mixed results over the course of the 7 years of experimentation (Table 4). LGP led to greater steer performance than HGP in 10 of 21 nutrient source-year combinations. As well, no significant differences occurred in eight combinations, but three occurrences led to poorer steer performance. The majority of effects suggest that reducing grazing pressure can improve steer performance.

\section{Steer gain ha ${ }^{-1}$}

A common method of assessing productivity of pastures is with steer gain ha ${ }^{-1}$, as this response integrates steer stocking rate as a function of forage production and steer performance. Similar to that of stocking rate and average daily gain, steer gain ha ${ }^{-1}$ varied widely within a year, among years and between grazing pressure treatments (Fig. 2). Several significant nutrient source $\times$ forage utilization interactions occurred with gain ha ${ }^{-1}$.

Steer gain ha ${ }^{-1}$ on a seasonal basis was most often similar between grazing pressure treatments (16 of 28 seasons), but there were also six seasons when gain $\mathrm{ha}^{-1}$ was lower with LGP than with HGP and six seasons when gain ha ${ }^{-1}$ was greater with LGP than with HGP. The coefficient of variation among the 28 seasons was slightly reduced with LGP $(81 \%)$ compared with HGP $(88 \%)$, indicative of only slight alleviation of 


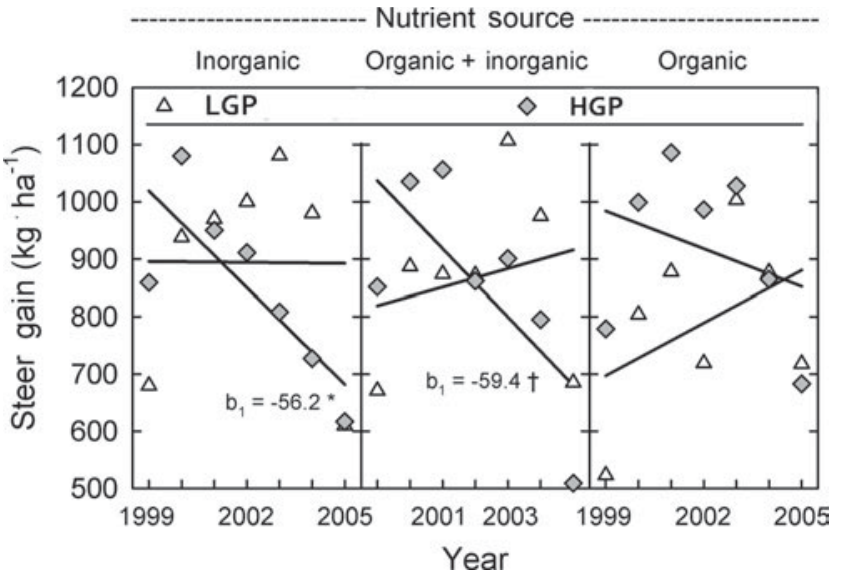

Figure 3 Relationship of time to steer gain ha ${ }^{-1}$ as affected by nutrient source and forage utilization regimes at Farmington, Georgia. $\dagger$ and $*$ indicate significance of slope coefficient at $P=0.1$ and $P=0.05$, respectively. LGP, low grazing pressure; HGP. high grazing pressure.

environmental stress on steer production. The greater forage dry mass with LGP than with HGP allowed some buffering of variations in the environment on forage availability and intake.

Steer gain ha ${ }^{-1}$ was rather low, but surprisingly greater with LGP than with HGP in the autumn (134 versus $120 \mathrm{kgha}^{-1}$, respectively; $\left.P=0.10\right)$ and in the winter (71 versus $44 \mathrm{kgha}^{-1}$, respectively; $P=0.003$ ). It was not different between grazing pressure treatments in the spring $\left(403 \mathrm{kgha}^{-1}\right)$. However, in the summer, steer gain $\mathrm{ha}^{-1}$ was lower with LGP than with HGP (260 versus $320 \mathrm{kgha}^{-1}$, respectively; $\left.P=0.002\right)$. The summer response was associated with a significant nutrient source interaction with grazing pressure, in which steer gain $\mathrm{ha}^{-1}$ was not significantly different between grazing pressure treatments with inorganic fertilization $\left(304 \mathrm{~kg} \mathrm{ha}^{-1}\right)$, but was lower with LGP than with HGP under organic+ inorganic fertilization (265 versus $316 \mathrm{~kg} \mathrm{ha}^{-1}$, respectively) and under organic fertilization (222 versus $336 \mathrm{~kg}$ ha $^{-1}$, respectively).

Over the entire 7-year period, steer gain ha ${ }^{-1}$ was not different between grazing pressure treatments when averaged across nutrient sources $\left(863 \mathrm{~kg} \mathrm{ha}^{-1}\right)$ (Table 5). However, there was lower gain $\mathrm{ha}^{-1}$ with LGP than with HGP under organic only fertilization (789 versus $918 \mathrm{~kg}$ $\mathrm{ha}^{-1}$, respectively). Steer gain ha ${ }^{-1}$ was lower with LGP than with HGP in 1999, 2000 and 2001. There was no difference between treatments in 2002 but then there was a reversal of effects in 2003 and 2004 (and a similar trend in response in 2005). Steer gain ha ${ }^{-1}$ significantly declined with time under HGP when nutrient source was inorganic only or organic + inorganic fertilization, but was unchanged with time under LGP (Fig. 3). A difference in temporal trend with respective to forage utilization regime also occurred during Phase 1, but in contrast to increasing gain $\mathrm{ha}^{-1}$ under LGP and stable gain ha ${ }^{-1}$ under HGP in

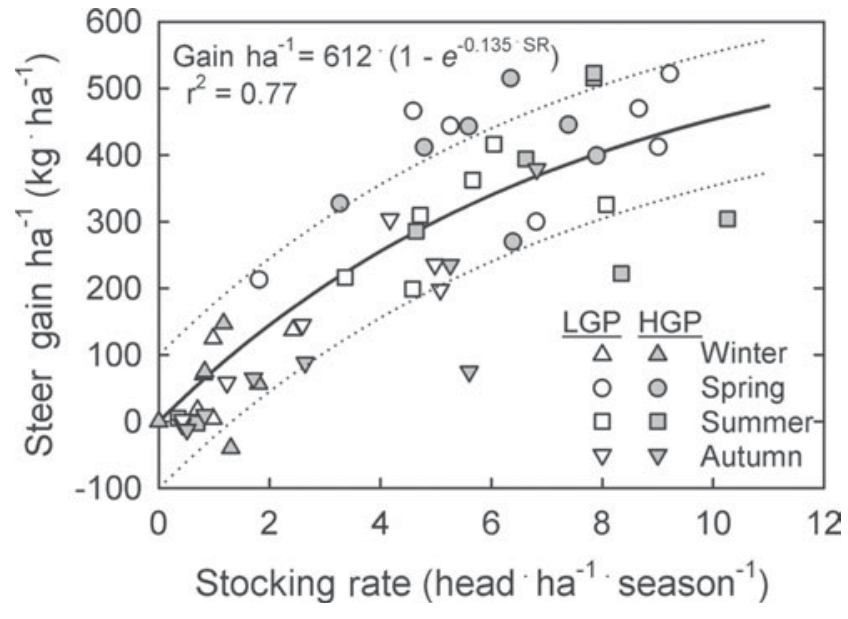

Figure 4. Relationship of steer gain ha ${ }^{-1}$ to stocking rate as affected by season and forage utilization regime at Farmington, Georgia. LGP, low grazing pressure; HGP, high grazing pressure. Dotted lines represent arbitrary boundaries of $\pm 100 \mathrm{~kg} \mathrm{ha}^{-1}$ from the regression relationship for illustrative purposes only.

Phase $1^{20}$, we observed stable gain ha ${ }^{-1}$ under LGP and declining gain $\mathrm{ha}^{-1}$ under HGP in Phase 2 (Fig. 3). The net difference between these two phases of the study was the same; although gain $\mathrm{ha}^{-1}$ became increasingly more improved with time under LGP relative to that under HGP. This differential response between grazing pressures with time suggests that accumulation of residual forage mass was better able to protect the pasture production system from the vagaries of weather-related and other environmental stresses.

Compared with Phase 1 of this experiment, steer gain $\mathrm{ha}^{-1}$ improved by $51 \%$ under LGP and $22 \%$ under $\mathrm{HGP}^{20}$ (Table 5). Greater animal production was a result of more grazing days, despite the lower animal performance during the cooler portions of the year. Considering only the spring and summer grazing seasons in Phase 2, steer gainha ${ }^{-1}$ was $666 \mathrm{kgha}^{-1}$ under LGP and $722 \mathrm{~kg} \mathrm{ha}^{-1}$ under HGP, values that were similar to those in Phase 1 (578 and $726 \mathrm{~kg} \mathrm{ha}^{-1}$ under LGP and HGP, respectively). Therefore, introduction of tall fescue into bermudagrass sod did not adversely affect animal production during the spring and summer, but rather simply added to animal production during the remainder of the year.

Considering the period of 2001-2004 when more complete full-year grazing was logistically possible, steer gain ha ${ }^{-1}$ averaged $930 \mathrm{~kg} \mathrm{ha}^{-1}$, a value similar to mean steer gain of $970 \mathrm{kgha}^{-1}$ from southern Georgia on different improved bermudagrass cultivars ${ }^{25}$. The high gain $\mathrm{ha}^{-1}$ from mixed tall fescue-bermudagrass pastures is encouraging, given that the cool-season forage was ergot-alkaloid producing. Other mixed-forage pastures may be potentially even more productive, as well as environmentally sustainable with regard to restoration of soil organic matter ${ }^{26}$. Further research on alternative 
forages should be conducted in a long-term, holistic experimental setting, since time and multidisciplinary interactions were shown to be important in the current experiment as well.

\section{Relationships among response variables and general discussion}

Relationships among stocking weight, stocking rate, average daily gain and gain ha ${ }^{-1}$ were all positively significant $(n=56$; averaged across nutrient sources as in Fig. 2). Strongest relationships were between stocking rate and steer gain ha ${ }^{-1}$ (Fig. 4). Stocking rate varied due to availability of forage at the time of stocking and the projection for continued forage growth during the remainder of the stocking period. Steer gain $\mathrm{ha}^{-1}$, therefore, became highly dependent on stocking rate. Steer performance was a secondary variable that affected the scatter in the relationship between stocking rate and gain $\mathrm{ha}^{-1}$. There were some key outlying points in the relationship that indicated differences in how average daily gain might have played a role. Four steer gain ha ${ }^{-1}$ observations fell $100 \mathrm{kgha}^{-1}$ below the regression relationship, all of which were under HGP and two of which were in summer (2003 and 2005) and one each in autumn (2004) and winter (2005). All of these periods (except winter 2005) had low average daily gain $\left(0.28 \pm 0.07 \mathrm{~kg} \mathrm{~d}^{-1}\right)$ and relatively high stocking rate $\left(8.1 \pm 2.3\right.$ steers ha $\left.^{-1}\right)$, suggestive that poor performance was likely associated with significant ergot alkaloid consumption from abundant forage. Residual forage dry mass at the end of those periods was $1.5 \pm 0.2 \mathrm{Mgha}^{-1}$, a level that likely exposed a high proportion of tall fescue forage for consumption compared with bermudagrass. Winter 2005 had low average daily gain $\left(-0.35 \mathrm{~kg} \mathrm{~d}^{-1}\right)$ and low stocking rate $\left(1.3\right.$ steers ha $\left.^{-1}\right)$, and therefore, the lack of fit with the relationship was likely due to both ergot-alkaloid containing forage and low available forage.

In contrast, almost all of the steer gain ha ${ }^{-1}$ observations that were $>100 \mathrm{kgha}^{-1}$ above the regression relationship in Figure 4 occurred during the spring $(n=6)$ or summer $(n=2)$. Most of these observations $(n=6)$ were also under HGP. These results suggest that the spring and early summer period was not necessarily a period of reduced animal performance, since all of these periods had high average daily gain $\left(0.89 \pm 0.15 \mathrm{~kg} \mathrm{~d}^{-1}\right)$ and moderate stocking rate $\left(5.7 \pm 1.6\right.$ steers ha $\left.{ }^{-1}\right)$. These observations are in contrast to previous literature, which indicates the greatest period of depressed animal performance from consuming ergot-alkaloid-containing tall fescue is in the spring and autumn ${ }^{5,27,28}$. It is possible that dilution of late-spring tall fescue forage consumption with emergent bermudagrass forage may have overcome any ergot-alkaloid consumption issue. In addition, maintaining low forage dry mass of tall fescue during the spring has been hypothesized as a strategy to minimize toxicity
(J.A. Stuedemann, unpublished data). Residual forage dry mass was $1.3 \pm 0.7 \mathrm{Mgha}^{-1}$ among these eight periods with high average daily gain.

Wide variations in seasonal values of animal responses (i.e., stocking density, stocking rate, average daily gain and gain $\mathrm{ha}^{-1}$ ) illustrate the need for graziers to anticipate changes in seasonal weather conditions (Fig. 2). If rainfall and temperature could have been anticipated better, it is possible that a smoother temporal dynamic might have resulted. However, this dynamic also shows the difficulty in closely managing pastures to preset targets. These data indicate that good times on pasture are often followed by hard times and vice versa. Therefore, a conservative approach to stocking could help moderate extreme pasture conditions. In contrast, reactionary stocking to take advantage of available forage likely led to consumption of higher quality forage, as documented in other studies $^{14,29}$. The put-and-take stocking system employed in this study can therefore be considered a hybrid stocking method between continuous and rotational stocking. Further research is needed to understand whether the dynamic pasture responses reported here might be found in more traditionally defined continuous stocking or rotationally grazed pastures.

Mixed-species composition of pastures was considered to be a more sustainable pasture system to allow nutrients to be used more effectively by actively growing forage throughout the year, rather than potentially lost during dormancy. In addition, filling dormant periods with a desired perennial forage species reduces the opportunity for weeds to develop and reduces resource requirements (e.g. labor, fuel and time for overseeding of annual forages). We have been measuring environmental indicators in this study, but they will be reported elsewhere.

The high rates of nutrient sources applied $(285 \pm 45 \mathrm{~kg}$ $\mathrm{Nha}^{-1} \mathrm{yr}^{-1}$ as inorganic, organic +inorganic and organic) were likely key contributors to the excellent forage and steer production in this study. The amount of $\mathrm{N}$ harvested from grazed pastures can be assumed to be $3 \%$ of live-weight gain ${ }^{30}$. Therefore, $\mathrm{N}$ removal with steer production would have been only $26 \pm 5 \mathrm{~kg} \mathrm{Nha}^{-1} \mathrm{yr}^{-1}$. We also measured total soil $\mathrm{N}$ accumulation in the $0-6-\mathrm{cm}$ depth of soil in these pastures as $74 \pm 5 \mathrm{~kg} \mathrm{Nha}^{-1} \mathrm{yr}^{-126}$ and accumulation in the $0-60-\mathrm{cm}$ depth of soil as $239 \pm 27 \mathrm{~kg} \mathrm{Nha}^{-1} \mathrm{yr}^{-110}$. Therefore, at least during the first 12 years of this experiment (Phases 1 and 2), most of the $\mathrm{N}$ applied to the pasture could be accounted for as harvested in cattle gain and stored in soil organic matter. There is the possibility that total soil $\mathrm{N}$ accumulation included a significant fraction of inorganic $\mathrm{N}$ that would be potentially mobile to the groundwater if leached or denitrified by soil bacteria in situ. Soil-profile inorganic $\mathrm{N}$ dynamics will be reported elsewhere. Rate of $\mathrm{N}$ application to well-developed pastures should decline with time to coincide with slower soil organic matter accumulation rates. 


\section{Conclusions}

Stocker grazing of mixed tall fescue-bermudagrass pastures in the Piedmont of Georgia was highly successful in achieving adequate steer performance $(0.61 \pm 0.12 \mathrm{~kg}$ $\mathrm{d}^{-1}$, mean \pm standard deviation among 42 nutrient source $\times$ forage utilization $\times$ year combinations) and steer production $\left(863 \pm 157 \mathrm{kgha}^{-1}\right)$. Reducing grazing pressure to increase $(P<0.001)$ residual forage dry mass from $1.46 \pm 0.29 \mathrm{Mg} \mathrm{ha}^{-1}$ (HGP) to $1.97 \pm 0.32 \mathrm{Mgha}^{-1}$ (LGP) resulted in a reduction $(P<0.001)$ in steer stocking rate from $4.2 \pm 0.8$ steers ha $^{-1}$ (HGP) to $3.7 \pm 1.1$ steers ha $^{-1}$ (LGP). However, the reduction in grazing pressure was able to increase $(P<0.001)$ steer performance from $0.58 \pm 0.11 \mathrm{~kg} \mathrm{~d}^{-1}$ (HGP) to $0.64 \pm 0.12 \mathrm{~kg} \mathrm{~d}^{-1}$ (LGP), which resulted in nearly equivalent $(P=0.24)$ steer production of $876 \pm 156 \mathrm{kgha}^{-1}$ (HGP) and $850 \pm$ $160 \mathrm{~kg} \mathrm{ha}^{-1}$ (LGP).

Nutrient source regime had little effect on residual forage mass level and on steer stocking rate and, therefore, broiler litter fertilization could be considered as effective as inorganic fertilizer in supplying sufficient nutrients for forage growth. However, the responses of steer performance and steer gain $\mathrm{ha}^{-1}$ were sensitive to nutrient source. Average daily gain under LGP was greater than under HGP with inorganic only and organic + inorganic fertilization, but was similar between grazing pressures under organic fertilization. This translated into no difference in gain $\mathrm{ha}^{-1}$ between grazing pressures with inorganic only and organic + inorganic fertilization, but lower gain ha ${ }^{-1}$ under LGP than under HGP with organic fertilization. The reason for this reduction in steer performance and production with organic fertilization under LGP could be linked to ingestion of a greater proportion of ergotalkaloid-containing tall fescue forage or more potent concentration of such toxins in association with high broiler litter application.

The temporal shift from lower steer production with LGP than with HGP early in the study toward greater steer production with LGP than with HGP later in the study was a significant outcome of this study. This result suggests that more moderate grazing pressure in a tall fescue-bermudagrass pasture system will improve long-term sustainability, by allowing a greater buffer of residual forage mass to overcome environmental stresses caused by periods of short-term drought, as well as a more robust root system to absorb nutrients in the soil profile.

Resource efficiency of the tall fescue-bermudagrass pastures evaluated in this study was considered high for a number of reasons. First, utilization of broiler litter as a nutrient source utilized a locally abundant resource. The concerns with nutrient imbalance and potential water quality deterioration with repeated broiler litter still needs to be assessed in comparison with mixed inorganic and organic sources. Second, a nearly year-round grazing system was possible with mixed tall fescue-bermudagrass pastures to utilize land resources efficiently, as well as to improve the quality of degraded cropland. Third, targeted anthelmintic treatment of steers in spring and autumn reduced reliance on therapeutic drug treatment and kept pastures free of gastro-intestinal parasites.

We conclude that excellent cattle performance and productivity can be achieved with broiler litter fertilization of strategically grazed pastures with mixed tall fescue-bermudagrass forage composition. Combined with results from botanical composition changes during this experiment ${ }^{22}$, a strategically grazed system would rely on closely grazing the robust tall fescue component during late winter to early spring and moderately grazing the bermudagrass component during the summer and autumn. These results can be used by producers to improve the sustainability of cattle grazing systems in warm, humid climates.

Acknowledgements. We appreciate the excellent technical support from Steve Knapp and many co-workers throughout the years of this experiment (David Lovell, Robert Sheats, Fred Hale, Eric Elsner, Robert Martin, Devin Berry, Heather Hart and Kim Lyness).

\section{References}

1 USDA-NASS (National Agricultural Statistics Service). 2007. Census of Agriculture, Volume 1, U.S. Summary and State Reports. Available at Web site http://www.agcensus. usda.gov/Publications/2007/Full_Report/index.asp (accessed March 30, 2012).

2 Sanderson, M.A., Franzluebbers, A., Goslee, S., Kiniry, J., Owens, L., Spaeth, K., Steiner, J., and Veith, T. 2011. Pastureland conservation effects assessment project: Status and expected outcomes. Journal of Soil and Water Conservation 66:148A-153A.

3 Read, J.C. and Camp, B.J. 1986. The effects of the fungal endophyte Acremonium coenophialum in tall fescue on animal performance, toxicity, and stand maintenance. Agronomy Journal 78:848-850.

4 Gunter, S.A. and Beck, P.A. 2004. Novel endophyte-infected tall fescue for growing beef cattle. Journal of Animal Science 82:E75-E82.

5 Franzluebbers, A.J. and Stuedemann, J.A. 2006. Pasture and cattle responses to fertilization and endophyte association in the southern Piedmont, USA. Agriculture, Ecosystems and Environment 114:217-225.

6 Hopkins, A.A. and Alison, M.W. 2006. Stand persistence and animal performance for tall fescue endophyte combinations in the South Central USA. Agronomy Journal 98:1221-1226.

7 Bouton, J.H., Gates, R.N., Belesky, D.P., and Owsley, M. 1993. Yield and persistence of tall fescue in the southeastern coastal plain after removal of its endophyte. Agronomy Journal 85:52-55.

8 Burns, J.C., Fisher, D.S., and Rottinghaus, G.E. 2006. Grazing influences on mass, nutritive value, and persistence of stockpiled Jesup tall fescue without and with 
novel and wild-type fungal endophytes. Crop Science 46:1898-1912.

9 Vibart, R.E., Drewnoski, M.E., Poore, M.H., and Green, J.T. Jr 2008. Persistence and botanical composition of Jesup tall fescue with varying endophyte status after five years of stockpiling and intensive winter grazing. Online. Forage and Grazinglands doi:10.1094/FG-2008-0421-01-RS.

10 Franzluebbers, A.J. and Stuedemann, J.A. 2009. Soil-profile organic carbon and total nitrogen during 12 years of pasture management in the Southern Piedmont USA. Agriculture, Ecosystems and Environment 129:28-36.

11 Guerrero, J.N., Conrad, B.E., Holt, E.C., and Wu, H. 1984. Prediction of animal performance on bermudagrass pasture from available forage. Agronomy Journal 76:577-580.

12 Roth, L.D., Rouquette, F.M. Jr, and Ellis, W.C. 1990. Effects of herbage allowance on herbage and dietary attributes of Coastal bermudagrass. Journal of Animal Science 68:193-205.

13 Franzluebbers, A.J., Wilkinson, S.R., and Stuedemann, J.A. 2004. Bermudagrass management in the Southern Piedmont USA. X. Coastal productivity and persistence in response to fertilization and defoliation regimes. Agronomy Journal 96:1400-1411.

14 Burns, J.C. and Fisher, D.S. 2008. 'Coastal' and 'Tifton 44' bermudagrass availability on animal and pasture productivity. Agronomy Journal 100:1280-1288.

15 Sollenberger, L.E. and Newman, Y.C. 2007. Grazing management. In R.F Barnes, C.J. Nelson, K.J. Moore, and M. Collins (eds). Forages, Vol. II, The Science of Grassland Agriculture, 6th ed. Wiley-Blackwell, Ames, IA. p. 651-659.

16 Steiner, J.L. and Franzluebbers, A.J. 2009. Farming with grass-for people, for profit, for production, for protection. Journal of Soil and Water Conservation 64:75A-80A.

17 Brown, M.A., Brown, A.H. Jr, Jackson, W.G., and Miesner, J.R. 2001. Genotype $\times$ environment interactions in milk yield and quality in Angus, Brahman, and reciprocalcross cows on different forage systems. Journal of Animal Science 79:1643-1649.

18 Rayburn, E.B. 1993. Tall fescue management. Available at Web site http://www.caf.wvu.edu/ forage/tallfesc.htm (accessed March 30, 2012).

19 Smith, S.R., Hall, J.B., Johnson, G.D., and Peterson, P.R. 2009. Making the Most of Tall Fescue in Virginia.
Available at Web site http://pubs.ext.vt.edu/418/418-050/ 418-050.html (accessed March 30, 2012).

20 Stuedemann, J.A. and Franzluebbers, A.J. 2007. Cattle performance and production when grazing Bermudagrass at two forage mass levels in the southern Piedmont. Journal of Animal Science 85:1340-1350.

21 Bransby, D.I. 1989. Compromises in the design and conduct of grazing experiments. In G.C. Marten (ed.). Grazing Research: Design, Methodology, and Analysis. Crop Science Society of America Special Publication Number 16. CSSAASA, Madison, WI, p. 53-67.

22 Franzluebbers, A.J., Seman, D.H., and Stuedemann, J.A. 2012. Forage dynamics in mixed tall fescue-bermudagrass pastures of the Southern Piedmont USA. Agriculture, Ecosystems and Environment (in press).

23 Stuedemann, J.A. and Hoveland, C.S. 1988. Fescue endophyte: history and impact on animal agriculture. Journal of Production Agriculture 1:39-44.

24 Franzluebbers, A.J., Seman, D.H., and Stuedemann, J.A. 2009. Tall fescue persists and cattle perform well on a novel-endophyte association in the Southern Piedmont USA. Online. Forage and Grazinglands doi:1094/FG-20090227-01-RS.

25 Hill, G.M., Gates, R.N., and Burton, G.W. 1993. Forage quality and grazing steer performance from Tifton 85 and Tifton 78 bermudagrass pastures. Journal of Animal Science 71:3219-3225.

26 Franzluebbers, A.J. and Stuedemann, J.A. 2010. Surface soil changes during twelve years of pasture management in the Southern Piedmont USA. Soil Science Society of America Journal 74:2131-2141.

27 Belesky, D.P., Robbins, J.D., Stuedemann, J.A., Wilkinson, S.R., and Devine, O.J. 1987. Fungal endophyte infection-loline derivative alkaloid concentration of grazed tall fescue. Agronomy Journal 79:217-220.

28 Belesky, D.P., Stuedemann, J.A., Plattner, R.D., and Wilkinson, S.R. 1988. Ergopeptine alkaloids in grazed tall fescue. Agronomy Journal 80:209-212.

29 Pedreira, C.G.S., Sollenberger, L.E., and Mislevy, P. 1999. Productivity and nutritive value of 'Florakirk' bermudagrass as affected by grazing management. Agronomy Journal 91:796-801.

30 NRC (National Research Council) 1996. Nutrient Requirements of Beef Cattle. 7th ed. National Academy Press, Washington, DC. 